\title{
Impressões sobre o ensinar e o aprender em tempos de pandemia de COVID-19
}

\begin{abstract}
Ana Lucia Gomes ${ }^{1}$
\section{RESUMO}

A severidade da pandemia do COVID-19 levou à adoção de medidas para diminuir o contágio entre as pessoas pelo vírus. Considerando a dinâmica escolar, que envolve interação próxima e aglomerações, decidiu-se pela suspensão das atividades escolares presenciais. Face a possíveis efeitos negativos na aprendizagem optou-se pela continuidade do ensino de forma remota. O presente trabalho busca refletir sobre as impressões que professores, alunos e pais têm a respeito do processo de ensinoaprendizagem remoto usado pelas escolas particulares da cidade do Rio de Janeiro ante a pandemia. $O$ estudo de natureza qualitativa e exploratória, envolveu 36 participantes. Como metodologia usamos a entrevista não-estruturada. Os resultados sinalizaram especificidades de cada grupo e indicaram que apesar das dificuldades enfrentadas eles desenvolveram uma nova postura diante do processo de ensinoaprendizagem como um todo e descobriram outras possibilidades para ensinarem e aprenderem no contexto do ensino emergencial a distância.
\end{abstract}

PALAVRAS-CHAVE: Ensino-aprendizagem. Ensino remoto. Pandemia COVID-19.

Impressions about teaching and learning in times of COVID-19 pandemic

\begin{abstract}
The severity of the COVID-19 pandemic led to the adoption of measures to decrease the contagion between people by the virus. Considering the school dynamic, which involves close interaction and crowds, it was decided to suspend face-to-face school activities. In view of the possible
\end{abstract}

\footnotetext{
${ }^{1}$ Doutora em Psicologia. Universidade do Estado do Rio de Janeiro (UERJ), Bolsista CEDERJ, Rio de Janeiro, RJ, Brasil. Orcid.: https://orcid.org/0000-0002-6235-8847. E-mail: ms.alfg@ gmail.com.
} 
negative effects on learning, it was decided to continue teaching remotely. This paper seeks to reflect on the impressions that teachers, students, and parents have about the remote teaching-learning process used by private schools in the city of Rio de Janeiro in the face of the pandemic. The study, qualitative and exploratory in nature, involved 36 participants. We used unstructured interviews as methodology. The results pointed out specificities of each group and indicated that despite the difficulties they faced they developed a new posture towards the teaching-learning process as a whole and discovered other possibilities for teaching and learning in the context of emergency distance learning.

KEYWORDS: Teaching-learning process. Remote education. COVID-19 pandemic.

Impresiones sobre la enseñanza y el aprendizaje en tiempos de la pandemia de COVID-19

\section{RESUMEN}

La gravedad de la pandemia de COVID-19 llevó a la adopción de medidas para disminuir el contagio entre personas por el virus. Teniendo en cuenta la dinámica escolar, que implica una estrecha interacción y aglomeraciones, se decidió suspender las actividades escolares presenciales. En vista de los posibles efectos negativos sobre el aprendizaje, se decidió seguir dando clases a distancia. Este trabajo pretende reflexionar sobre las impresiones que tienen los profesores, los alumnos y los padres sobre el proceso de enseñanza-aprendizaje a distancia utilizado por las escuelas privadas de la ciudad de Río de Janeiro antes de la pandemia. El estudio, de carácter cualitativo y exploratorio, contó con 36 participantes. Como metodología se utilizó la entrevista no estructurada. Los resultados señalaron las especificidades de cada grupo e indicaron que, a pesar de las dificultades enfrentadas, desarrollaron una nueva postura hacia el proceso de enseñanzaaprendizaje en su conjunto y descubrieron otras posibilidades de enseñar y aprender en el contexto de la educación a distancia de emergencia.

PALABRAS CLAVE: Enseñanza-aprendizaje. Educación remota. Pandemia COVID-19.

$$
* * *
$$




\section{Introdução}

A severidade da pandemia do COVID-19 em todo o mundo levou à adoção de medidas que visassem diminuir as chances de contágio entre as pessoas pelo vírus, tais como: realização da quarentena, evitar o uso do transporte público, praticar o distanciamento social, realizar o trabalho de forma remota, bem como, o ensino (SEN-CROWE; MCKENNY; ELKBULI, 2020).

De acordo com a literatura (ARRUDA, 2020; SENHORAS, 2020), a infecção de jovens pelo COVID-19 tende a ser leve e isso, de certa forma, se torna um grande problema. Crianças e adolescentes podem transmitir o vírus sem saberem que estão contaminados, colocando outras pessoas em risco, ante a possibilidade de uma vez infectadas, desenvolverem um quadro clínico severo que requer cuidados médicos intensivos (SENCROWE; MCKENNY; ELKBULI, 2020).

Isso posto e considerando o espaço e a dinâmica escolar, que invariavelmente, envolvem interação próxima e aglomerações decidiu-se pela suspensão das atividades escolares presenciais. Acreditando que a interrupção das aulas sem uma previsão concreta para o seu retorno poderia impactar negativamente os alunos, optou-se pela continuidade do ensino de forma remota (ARRUDA, 2020; BURGESS; SIEVERTSEN, 2020; SENHORAS, 2020).

A transição do ensino presencial para a versão remota nas escolas brasileiras ocorreu em um curto espaço de tempo, de 15 dias a no máximo um mês, dada a urgência de retomada da rotina escolar pelos alunos. O tempo de preparo foi importante tanto para a estruturação do ambiente virtual de aprendizagem pela escola, quanto para a organização das famílias visando conciliar o trabalho dos pais, os estudos dos filhos e os suportes tecnológicos disponíveis, para que todos pudessem realizar suas tarefas em casa.

Na cidade do Rio de Janeiro, contexto de análise deste estudo, verificou-se que as escolas particulares, tiveram em média 15 dias para organizarem o preparo das aulas remotas. Esse período também incluiu a preparação dos 
professores para o uso da plataforma de aula virtual e a orientação aos pais sobre como será o ensino a distância (RONDINI; PEDRO; DUARTE, 2020).

Para a grande maioria dos professores o tempo destinado para a construção de um novo fazer pedagógico foi insuficiente. Não houve tempo para atender às várias questões que surgiram durante o processo de construção e adaptação ao ensino remoto, tais como, o entendimento sobre o funcionamento de uma sala de aula virtual, como e quais recursos podem ser usados para compor a aula e como criar um ambiente de aprendizagem estimulante e desafiador (ARRUDA, 2020).

Observamos que os docentes participaram de várias reuniões e grupos de trabalho para terem maiores informações sobre como é o ensino online e garantirem a continuidade do processo educacional. Logo, a falta de experiência didático-metodológica dos professores com o ensino remoto fez com que as aulas fossem planejadas de modo intuitivo, buscando adaptar o conteúdo às ferramentas educacionais digitais disponibilizadas pela escola. Assim, tenderam a transferir para o ambiente virtual, o modelo presencial de ensino, cuja metodologia não possui o mesmo efeito, posto que o ensino a distância tem características e dinâmicas próprias, implicando no desenvolvimento de um fazer-pedagógico diferenciado.

Por conseguinte, o presente trabalho propõe uma reflexão sobre as impressões que professores, alunos e pais têm em relação ao processo de ensino-aprendizagem remoto usado pelas escolas particulares da cidade do Rio de Janeiro, Brasil, considerando o contexto da pandemia do novo coronavírus.

Realizamos um estudo exploratório, de natureza qualitativa. Os participantes foram convidados à falar livremente sobre como estão vivenciando a experiência do ensino remoto em tempos de pandemia de COVID-19.

Participaram do estudo 36 sujeitos de duas escolas particulares, cujo público majoritariamente pertence à classe média. Ambas as escolas são localizadas no município do Rio de Janeiro. Os sujeitos foram distribuídos equitativamente pelas duas escolas, definidas como A e B. Participaram 12 professores (06 do ensino fundamental e 06 do ensino médio), 12 alunos (06 
do ensino fundamental e 06 do ensino médio) e 12 responsáveis (06 do ensino fundamental e 06 do ensino médio). Não fizemos distinção com relação ao gênero dos participantes.

\section{Do presencial para o virtual: desafio aos professores}

$\mathrm{O}$ ensino a distância no Brasil teve início no século $\mathrm{XX}$, através dos cursos realizados por correspondência. Com o passar dos anos, a educação a distância foi atualizada face ao surgimento de novos suportes que permitiram uma nova forma de organização das aulas, bem como, o acesso às mesmas. Assim, verificamos cursos ocorrendo via rádio, TV e, mais recentemente, via internet (VIANNA; ATAIDE; FERREIRA, 2015).

Com a Lei 9.394/96, a Educação a Distância (EaD) foi regulamentada como modalidade educacional, em que o processo de ensino-aprendizagem ocorre de forma mediada por dispositivos atrelados à tecnologia da informação e comunicação, permitindo que a interação aluno-professor ocorra em um espaço-tempo distinto. O artigo $2^{\circ}$ do Decreto 5.622, de 19 de dezembro de 2005, ampliou a oferta do ensino a distância considerando, dentre outras áreas, a educação básica (DIAS; LEITE, 2010).

Segundo Arruda (2020), a EaD envolve uma série de ações especializadas visando a elaboração de estratégias de ensino que conjugam aspectos síncronos e assíncronos da aprendizagem. Por isso, o professor não trabalha sozinho na EaD, existe toda uma equipe que o assessora no desenvolvimento do seu trabalho garantindo a qualidade técnica, pedagógica e estética das suas aulas e dos materiais que utiliza como complementos.

Ante a suspensão das aulas presenciais, a escola teve que construir espaços de aprendizagens remotos, mas esses espaços tenderam a se afastar da estrutura característica da educação a distância. O que notamos nesse processo de adaptação da escola presencial foi o uso de variados recursos tecnológicos, com a finalidade de transferir a estrutura da aula presencial para o ambiente remoto, sem expressar o cuidado com a linguagem técnica e pedagógica inerentes à EaD. 
Não raro nos deparamos com a ideia de que para dar uma aula online bastaria agir como se fosse uma aula presencial. Disso, resultaram os vários problemas que verificamos na atual transição do ensino presencial para o remoto, dentre eles, a inadequação do material complementar e a subutilização das ferramentas tecnológicas. Ao que parece, as dificuldades observadas podem advir de a escola não ter considerado o quanto os professores sabem a respeito da relação entre tecnologia e práticas pedagógicas (GOMES, 2014; RONDINI; PEDRO; DUARTE, 2020). O curto espaço de tempo que as escolas tiveram para organizar e habilitar suas salas virtuais, parece tê-las levado a privilegiarem a preparação técnica do professor para o ensino online. No entanto, a maioria dos professores sinalizou dificuldades para pôr em prática o que tinha programado para os seus alunos, conforme podemos verificar nas falas abaixo:

"Ainda estou tateando na sala de aula remota. Nunca trabalhei tanto!! Seria mais fácil se tivesse alguém para explicar como tudo funciona, sinto que falta algo". (Professor, Ensino Fundamental I, escola A)

"Preparei os slides madrugada adentro e não consegui inserir na plataforma para apoiar a aula ao vivo. Os alunos tentaram ajudar, mas não houve jeito. Tive que improvisar." (Professor, Ensino Fundamental II, Escola B)

"Gravei o vídeo para a aula gravada. Estava em cima do prazo e postei na sala. Recebi uma mensagem do suporte dizendo que está grande e que precisaria editar. Como? Resolvi gravar de novo, um trabalho sem fim." (Professor, Ensino Médio, Escola B)

Ante a aparente falta de orientação sobre a didática e metodologia comumente empregadas na modalidade de EaD, os professores prepararam suas aulas a partir do que conhecem, ou seja, tomaram como base o modelo de ensino presencial e os recursos tecnológicos que usam em seu dia-a-dia. Além disso, muitos relataram sobre a falta de apoio de um especialista na área para ajudá-los com dicas sobre como deveriam organizar a aula, principalmente, com relação às aulas ao vivo e gravadas. 
"E de repente, além de professoras, nos tornamos youtubers! E como que a gente faz? No ensaio e erro! E é muito difícil gravar um vídeo. Grava. Desgrava. Grava. Desgrava. Sem fim." (Professor, Ensino Fundamental I, Escola B)

"Jamais imaginei viver isso. De repente, tenho que gravar aulas. Interagir ao vivo com os meus alunos, através de uma tela. Me sinto meio artificial. Não me sinto confortável. Seria ótimo termos alguém para ajudar nessa nova forma de dar aula. (Professor, Ensino Fundamental II, Escola B)

"Sinceramente, a gente tinha que ter feito um curso relâmpago sobre como gravar um vídeo. Um dia desses, assisti à uma aula gravada e achei horrível!! Depois disso, busquei informações para tentar melhorar. Sinto falta dessa orientação por parte da escola. Não há ninguém da área para ajudar. A gente vai fazendo e compartilha o que dá certo com os colegas." (Professor, Ensino Médio, Escola A)

A escola particular, em sua maioria, mostra-se atenta aos avanços da tecnologia voltados à educação (KENSKY, 2007). Tão logo um novo equipamento ou recurso surge, a escola volta-se a obtê-los, sob a premissa de que a qualidade do ensino tende a melhorar. No entanto, o que qualifica positivamente o ensino não é a tecnologia em si, mas a forma como o professor pode utilizá-la considerando o conteúdo pedagógico e o público a que se destina (GOMES, 2014). Uma vez que o professor compreenda como usar uma ferramenta tecnológica, ele tem a chance de explorá-la de forma produtiva e dessa forma, tem a possibilidade de tornar a aprendizagem dos alunos mais dinâmica e funcional.

As questões levantadas pelos professores entrevistados referentes a como se sentem despreparados e inadequados ante às atividades que precisam desenvolver, poderiam nem existir, se a escola tivesse um olhar cuidadoso para a formação continuada do professor.

A fala do professor do ensino fundamental II a seguir, exemplifica como a sua prática mudou a partir do momento em que ele entendeu como usar os recursos de edição para fazer os seus vídeos. Tal relato, reforça a importância dos docentes terem uma formação específica ou ao menos um especialista à disposição para assistí-los em suas dificuldades. 
"Aprender a usar o aplicativo de edição de vídeo foi um divisor de águas na minha vida como professora. Posso falar dos vídeos de antes, coitadinhos dos alunos [risos] e depois. Faz uma diferença enorme! Dá trabalho. Aliás, muito, mas vale a pena! Até me distraio preparando." (Professor, Ensino Fundamental II, Escola B)

O tempo sempre foi um desafio para o professor. O dia-a-dia, para a grande maioria, sempre se mostrou pesado, permeado por muitas demandas, precisando se dividir entre: escola(s), turmas, alunos, provas a serem planejadas e corrigidas, preparação de aulas, lançamentos de notas e sua vida pessoal, que encerra outro conjunto complexo de aspectos.

O novo contexto de trabalho advindo da pandemia do COVID-19 parece ter ampliado a rotina do professor levando-o à uma percepção do tempo ainda mais fugaz.

"O tempo para preparo das aulas é curto e ainda temos que dividir com a família e com as reuniões da escola. Tenho pelo menos duas por semana. Para dar conta tenho que trabalhar até mais tarde ou usar os fins de semana. Fico neste dilema." (Professor, Ensino Fundamental I, Escola A)

"Sinto muitas dificuldades para conciliar as tarefas de casa, as demandas da família e as atividades puxadas da escola, agora. Está complicado, ainda mais para mim, que tenho filhos pequenos e esposa, também professora. Sentiu o drama? Mas, a gente respira fundo e segue a caminhada." (Professor, Ensino Fundamental II, Escola B)

“Às vezes, aliás, muitas vezes, preparo minhas aulas ou faço os vídeos noite adentro. De dia é tanta coisa para fazer que nem sei ... Cuido das coisas de casa, ajudo meus filhos nos estudos, tem reunião da escola. Sinto que estou cansando. O ritmo está puxado, fora o estresse do coronavírus." (Professor, Ensino médio, Escola A).

Mas, ante o desafio do ensino remoto que exige do professor uma atuação proativa, sem oferecer em troca a devida capacitação sobre como deve atuar no ambiente virtual de aprendizagem, notamos que o professor não se intimidou e vêm se empenhando ao máximo. Destarte, buscam informações, apoiam uns aos outros e, sobretudo, contam com seus alunos, 
que como eles, também estão acertando e errando na experiência do ensino remoto em tempos de pandemia do COVID-19.

\begin{abstract}
"Semana passada meu filho fez uma participação especial, não programada, na minha aula ao vivo [risos]. Os alunos adoraram. Fiquei sem jeito, mas até que foi bom, porque demos aquela respirada..." (Professor, Ensino Fundamental II, Escola A).

"Até que o momento, apesar de difícil, faz a gente querer aprimorar. Tenho estudado sobre o ensino a distância e procuro por aplicativos que possam me ajudar a deixar a aula mais leve. O meu maior objetivo é deixá-los [os alunos] menos estressados e mais atentos. Uso a voz do Darth Vader para falar com os meus alunos, escrevo usando muitas cores, enfim, vou criando e eles vão respondendo positivamente. Ganha todo mundo!" (Professor, Ensino Médio, Escola B)
\end{abstract}

\title{
Os alunos e a aprendizagem através da tela
}

A notícia de que as atividades escolares seriam continuadas de forma remota, em função da pandemia do novo coronavírus, foi recebida de forma positiva pela maioria dos alunos entrevistados independentemente do segmento que estudam. Tal reação não foi surpresa, considerando o notável interesse que possuem pelo contexto tecnológico e suas interfaces. A agilidade com que os alunos manipulam os recursos tecnológicos disponíveis acaba sendo um traço importante do comportamento da geração atual.

Ávidos pela tecnologia, em que destacamos o uso da internet e dos jogos eletrônicos, os alunos despendem inúmeras horas do seu dia na frente de uma tela (computador, notebook, celular ou tablet) e comumente, realizam inúmeras tarefas simultâneas ou não, indicando terem flexibilidade para lidarem com as múltiplas demandas presentes no contexto digital (GOMES; CORREA, 2009; ZOMER; SANTOS; COSTA, 2018).

No entanto, para a grande parte dos alunos, usar a internet para o lazer mostrou-se muito diferente de usá-la para o estudo, principalmente, para assistir às aulas regulares planejadas pela escola. A expectativa dos alunos com o processo de aprendizagem, considerando às narrativas analisadas, 
parece voltada para a ideia de que eles achavam que teriam uma experiência de aprendizagem mais prática e dinâmica, que proporcionasse mais autonomia para organizarem seus estudos. No entanto, essa "visão mágica" não se confirmou com as aulas regulares através do computador propostas pela escola, conforme podemos verificar com as falas a seguir.

"Não quero mais estudar no computador... quero ir para a escola." (Aluno, Ensino Fundamental I, Escola A)

"Gostei no início, quando não tinha vídeo e aula ao vivo. Quando tinha só os exercícios e slides era até legal." (Aluno, Ensino Fundamental II, Escola B)

"Confesso que fiquei animada com a notícia. Acho importante continuar com os estudos, principalmente, para a gente que está no Ensino Médio. Mas, ter aulas a distância é muito diferente do que imaginei. Está bem pesado." (Aluno, Ensino Médio, Escola A)

"Vamos para a segunda semana de aula e ainda estou me adaptando." (Aluno, Ensino Médio, Escola B)

De acordo com os alunos entrevistados, a rotina de aulas em todos os segmentos, mostrou-se carregada, na qual verificamos a combinação de aulas gravadas, aulas ao vivo e atividades distribuídas ao longo de todo o turno escolar.

Podemos supor, que as escolas pensaram a organização das aulas remotas a partir da dinâmica presencial de ensino, no qual verificamos inclusive, o uso de intervalos para os alunos descansarem. As duas escolas participantes deste estudo realizaram trabalhos bem parecidos. As diferenças verificadas referem-se à duração das aulas, especificamente, com relação ao ensino fundamental. A escola A organizou as atividades escolares para o período de 3 horas e a escola B, para o período de 4 horas. No tocante à carga horária do ensino médio, ambas as escolas seguiram os horários que mantinham no modelo presencial. Assim sendo, os alunos das escolas A e B tinham horários fixos para assistirem e realizarem as tarefas como "se estivessem na escola". 
Isso posto, não foi difícil prever que a estrutura adotada, fortemente enraizada no modelo presencial, geraria dificuldades no processo de aprendizagem remoto, tais como, desmotivação, falta de interesse, cansaço ou estresse, em conformidade com os relatos dos alunos abaixo.

"É a mesma coisa de antes. Aula, aula, aula. Tenho saudades da escola! Da minha professora, dos meus amigos... de todo mundo" (Aluno, Ensino Fundamental, I, Escola B)

"Tenho saudades dos meus amigos. A gente tem intervalo, mas não é como o recreio na escola. " (Aluno, Ensino Fundamental II, Escola A)

"As aulas são monótonas e temos muito conteúdo novo. Difícil concentrar. A gente passa muito tempo diante da tela e a escola não usa as ferramentas como deveria. Como está, não estou gostando, não. ” (Aluno, Ensino Médio, Escola B)

A crítica dos alunos ao modo de organização das aulas ratifica a hipótese de a escola não ter se preocupado com o aspecto didático-pedagógico adequados ao ensino remoto. A estrutura pensada mostrou-se ineficiente para manter o engajamento dos alunos, de forma constante e produtiva, durante as aulas em todos os segmentos observados.

Os relatos apresentados também nos levam a pensar que, diante da proposta do ensino remoto, os alunos esperavam um tipo diferenciado de aprendizagem, que lhes proporcionassem autonomia para construirem os seus conhecimentos, através das várias ferramentas disponíveis nessa modalidade de ensino. Mas, a rotina de aula mostrou-se tradicional e ainda mais pesada, exigindo do aluno uma dedicação maior aos estudos e parecer não considerar o contexto delicado que vivenciam referente à pandemia do novo coronavírus.

Apesar da dificuldade em manterem-se centrados durante as aulas online, os alunos entrevistados em sua maioria realizam as atividades propostas e buscam apoio da escola, através das figuras dos coordenadores, sempre que possuem algum problema. Os alunos do $8^{\circ}$ e $9^{\circ}$ anos do Ensino Fundamental II e do Ensino Médio, por terem maior autonomia, mostraram-se mais engajados na busca por um equilíbrio entre as demandas discentes e as da escola. 
Todos os alunos indicaram apoiar os seus professores e sempre que possível os auxiliavam, orientando sobre o uso de determinados recursos, oferecendo feedback sobre as atividades realizadas ou simplesmente, incentivando-os a continuarem. As falas a seguir ilustram esses aspectos:

"Eu achei que o vídeo de história não estava muito bom, mas eu disse que estava pra ela ficar feliz." (Aluno, ensino fundamental I, Escola A)

"Na sexta-feira a gente conversa com a professora sobre o que a gente mais gostou e o que não gostou tanto ou achou difícil.” (Aluno, Ensino Fundamental I, Escola B)

"Escrevemos uma carta para a coordenação pedindo que a escola desse uns 15 dias de revisão, pois estamos com muita matéria nova. Muitos alunos estão com muitas dúvidas, porque acumulou muita coisa. Acho que essas semanas de revisão será muito boa para todo mundo, não só para os alunos." (Aluno, Ensino Fundamental II, Escola A)

"Minha turma está puxando um abaixo-assinado para melhorar as nossas aulas. A gente quer que a escola faça alguma coisa. Os professores estão se empenhando muito. A gente conversa com eles, damos dicas e tal, mas é muita matéria nova... O professor não tem tempo para preparar com calma. Tudo é novo e para todo mundo. Precisamos melhorar porque acho que o ensino presencial vai demorar para voltar." (Aluno, Ensino Médio, Escola B)

\section{O entendimento dos pais sobre o ensino remoto e a aprendizagem dos seus filhos}

Os responsáveis preocupados com a formação acadêmica dos seus filhos, devido à possível descontinuidade da rotina diária de estudos, acataram a decisão das escolas de substituir o ensino presencial pelo ensino remoto, enquanto fosse necessária a prática do distanciamento social.

Com o recebimento da grade de aulas e as instruções gerais oferecidas pelas escolas, sobre como funcionaria o estudo remoto, os pais se depararam com alguns problemas, cuja complexidade variou de acordo com a escolaridade dos filhos e a dinâmica familiar. 
Os pais das séries iniciais, cujos filhos eram do ensino fundamental I, comentaram sobre a necessidade recorrente de precisarem interferir para que seus filhos realizassem as atividades programadas. A demanda, não esperada, desse suposto acompanhamento ativo sobrecarregou os responsáveis, dado que precisavam conciliar as atividades referentes ao trabalho com as tarefas escolares dos seus filhos. As falas seguintes ratificam essa ideia:

"Tive que encher o saco do meu filho para fazer a aula ao vivo. Fico o dia inteiro em torno disso. Sozinhos não assitem às aulas. Se distraem com muita facilidade. É extremamente cansativo. Só consigo trabalhar quando a aula acaba". (Responsável, Ensino Fundamental I, Escola A)

"A escola online está virando minha vida de cabeça pra baixo. Tenho que fazer tanta coisa com eles!", “Tenho trabalhado de madrugada para liberar o computador para a aula deles e estar disponível. Eu posso, até certo ponto, mexer no meu horário, eles não. Se não assistem, perdem conteúdo". (Responsável, Ensino Fundamental I, Escola B)

Nos outros segmentos, Ensino Fundamental II e Ensino Médio, a questão do acompanhamento dos estudos dos filhos não surgiu de forma veemente. Os pais demostraram menos preocupação em terem que "estudar com seus filhos". Alguns mencionaram acompanhar a rotina de estudos deixando-os mais "soltos". Provavelmente, a idade destes alunos, em torno de 11-17 anos, e a experiência escolar que têm corroboraram para o desenvolvimento de uma prática de estudo mais autônoma, em que os alunos recorreriam à ajuda dos pais, quando possuíssem alguma dúvida ou precisassem realizar algo mais elaborado, conforme podemos verificar através das falas abaixo.

“Aqui em casa conversamos sempre, mostrando que já estão grandinhos para terem responsabilidade e acompanharem as matérias sozinhos e que uma hora será cobrado. A única coisa que falo é para manter tudo em dia”. (Responsável, Ensino Fundamental II, Escola A).

"Acompanho os estudos, mas não estudo com eles. Digo apenas para não acumularem as tarefas e me procurarem se precisam de ajuda. Até o momento está dando certo." (Responsável, ensino fundamental II, Escola B) 
"Por aqui, deixo mais à vontade, algumas aulas gravadas eles assistem à tarde, dependendo do ânimo e do dia. Entro volta e meia no quarto, para ver se estão assistindo. E vamos seguindo!" (Responsável, Ensino Médio, Escola A)

"De vez em quando, pergunto como vão as aulas, sobre o que estão fazendo. Não fico cobrando muito. $O$ que percebo é a ansiedade para a volta às aulas". (Responsável, Ensino Médio, Escola B)

O cerne das preocupações dos pais recaiu na questão do aproveitamento dos seus filhos. Os responsáveis indicaram ter muitas dúvidas sobre a qualidade da aprendizagem e temem que defasagens importantes ocorram, em função do que observaram sobre a organização das aulas e a qualidade de alguns materiais que, por muitas vezes, não prendem a atenção ou despertam o interesse dos alunos.

"Penso que a escola deveria oferecer alternativas mais dinâmicas para ter a atenção e interesse do aluno. O planejamento deveria abordar os conteúdos de forma mais lúdica, com linguagem adequada e tempo, também adequado.” (Responsável, ensino fundamental I, Escola A)

"As videoaulas, gravadas ou ao vivo, são muito extensas. Às vezes, ultrapassam o tempo de aula, de 45 minutos. Meu filho já acumulou não sei quantos vídeos. Impossível, estar aprendendo dessa forma." (Responsável, Ensino Fundamental II, Escola A).

"São muitos conteúdos dados de maneira acelerada e ininterrupta. Poderia ter paradas para revisão. Isso me deixa muito preocupado e não confiante na qualidade da aprendizagem" (Responsável, ensino fundamental II, Escola B)

"Minha grande preocupação é como estão ficando os conceitos fundamentais e básicos. Acho que não serão bem aprendidos e isso impactará a vida escolar no futuro...enfim, vamos ver o que acontece. (Responsável, Ensino Médio, Escola B)

Outro aspecto que os responsáveis entrevistados sinalizaram consiste na falta de diálogo com a escola. Disseram não terem recebido informações suficientes sobre o planejamento pedagógico e de como seriam feitas as avaliações, conforme podemos observar com os relatos a seguir: 
“Tem adulto que não funciona com ensino a distância! Imagina eles! Já estamos fechando o $2^{\circ}$ mês de aulas e não temos nenhum retorno da escola sobre como foi 0 aproveitamento e como será para frente. Como pais e professores poderão dimensionar o aproveitamento das crianças?" (Responsável, Ensino Fundamental I, Escola A).

"Infelizmente, a escola precisou criar uma plataforma em 2 semanas, treinar professores, montar material didático e treinar alunos. Por isso, entendo os problemas, mas não fico tranquila. Falta uma conversa aberta com a gente para explicar como será." (Responsável, Ensino fundamental II, Escola A)

"Vamos fazer 2 meses sem nada saber da programação do conteúdo a ser abordado por matéria." (Responsável, Ensino Médio, Escola A)

"Vai ter prova? Vai ter reposição presencial das aulas? Revisão? Não sei te dizer. A escola não informa nada a respeito.” (Responsável, Ensino Médio, Escola B)

"Cada segmento tem as suas questões, mas acredito que para o ensino médio é pior. É muita matéria a ser dada... quem está no $1^{\circ}$ ano fará o EM em dois anos e meio. Quem está no $2^{\circ}$, que tem a maior parte da matéria, fará em um semestre e quem está no $3^{\circ}$ ano perdeu tanta coisa que quando penso neles fico com o coração apertado. Acho que não dá para recuperar... A escola erra em não acolher nossas demandas. Tinham que oferecer respostas menos impessoais." (Responsável, Ensino Médio, Escola A)

"Para os pequenos o maior problema é a alfabetização, atrasará uns 6 meses. Claro que a parada não é boa, mas eu acho que a escola fará algo mais específico na retomada das aulas presenciais. Assim espero, porque a única informação que tenho é que a escola está se empenhando ao máximo e etc etc.” (Responsável, Ensino Fundamental I, Escola B)

Sobre a avaliação dos alunos observamos que a maioria dos pais entende como necessária, mas espera que a escola pense o modus operandi do processo avaliativo com critério e cuidado, pois o momento requer atenção aos alunos, face as dificuldades que podem estar enfrentando relativas à pandemia do COVID-19 e à adaptação ao ensino remoto. As falas destacadas abaixo ilustram a preocupação dos pais com essa temática: 
"Ficamos entre a cruz e a caldeirinha, pois a avaliação é muito importante. Mas, seria muito desumano, na minha opinião, reprovar um aluno. A escola deve pensar em outro tipo de forma para avaliar o aluno. Ninguém está tranquilo para estudar e fazer prova.” (Responsável, Ensino Fundamental I, Escola A)

"Sou contra fazer avaliações valendo notas. Acho que os alunos deveriam fazer avaliações diagnósticas, para que os professores vejam o que precisam melhorar. Estão estressados, cansados com essa rotina e são muito pequenos, ainda. A escola ainda não se posicionou sobre isso, mas serei contra o uso de avaliações tradicionais." (Responsável, Ensino Fundamental, Escola B)

"A minha maior dúvida e acho que da maioria também, é como vai ficar a avaliação esse ano. Teremos o mesmo esquema de teste e prova? Isso seria certo, considerando a pandemia e as aulas da forma como estão ocorrendo? " (Responsável, Ensino fundamental II, Escola A)

"As provas fazem parte da rotina escolar. Elas precisam ocorrer, até para os professores saberem se os alunos estão aprendendo ou não, mas eu gostaria que elas acontecessem mais para frente, não enquanto temos o ensino a distância. Me incomoda não ter um posicionamento da escola sobre isso." (Responsável, Ensino Fundamental II, Escola B)

"Uma coisa que me incomoda muito é ver nossos filhos trancafiados no quarto, desde que tudo isso começou, só estudando, estudando e estudando. Imagina se tiver aquela rotina de provas, uma atrás da outra! Eu acho que não deve ter, mas também, são necessárias. Não sei o que pensar, ainda sofrem com a pandemia.” (Responsável, Ensino Médio, Escola A)

"Sobre as avaliações, acho que a escola deveria considerar o momento que os alunos estão passando e o nível de ansiedade que podem estar sofrendo. $\mathrm{O}$ resultado pode não ser condizente com o que sabem. Espero que a escola tenha esse cuidado." (Responsável, Ensino Médio, Escola B)

\section{Conclusão}

Diante da pandemia do novo coronavírus uma série de medidas precisaram ser adotadas de forma a tentar conter o vírus e minimizar o seu impacto na sociedade. Disso resultou na construção de novas formas de estar na sociedade, em que privilegiou-se a interação virtual como contraponto à 
necessidade de manter o distanciamento social. Assim, trabalhar, estudar, fazer compras, conversar ou realizar pequenas comemorações passaram a ocorrer tendo a tecnologia como a principal interface.

Com relação à educação, após menos de um mês de início das aulas, a escola e seus atores foram pegos de surpresa com a suspensão das aulas presenciais no estado do Rio de Janeiro. Acreditava-se que em torno de 15 dias, haveria um quadro positivo de enfrentamento ao novocoronavírus que guiaria a sociedade de volta à sua normalidade. Mas, isso não aconteceu. $\mathrm{O}$ número de contaminados pelo COVID-19 cresceu sublinhando a necessidade de manter as escolas com suas atividades presenciais interrompidas.

A escola, como um todo, parece ter privilegiado a ambientação do espaço de aprendizagem virtual. Inúmeros recursos tecnológicos foram disponibilizados para que o processo de ensino-aprendizagem ocorresse de forma produtiva e funcional para viabilizar a continuidade dos estudos.

À primeira vista, tudo pareceria ocorrer sem maiores problemas. Em 15 dias, aproximadamente, a escola virtual funcionava a pleno vapor, mas o tempo de preparação não foi suficiente para a ampla capacitação dos professores para ensinar a distância, como também, não foi o bastante para as escolas anteverem as dificuldades que os alunos teriam para realizar as tarefas em casa, considerando a dinâmica familiar.

Apesar da complexidade da situação que todos enfrentam, envolvendo as especificidades do ensino remoto e os desdobramentos da pandemia de COVID19, verificamos grande esforço dos professores, alunos e pais para criarem um ambiente de aprendizagem minimamente funcional e, sobretudo, acolhedor.

As falas apresentadas indicaram existir um distanciamento da escola, enquanto instituição, para o processo de ensino-aprendizagem em si, que se constrói na relação entre aluno e professor e não, pelo uso da tecnologia em si. A escola preocupada em garantir uma "estrutura de aprendizagem remota" parece ter deixado em segundo plano, a formação do professor, ou seja, o que ele entende e precisa saber sobre como é ensinar a distância. Se a escola tivesse tido o mínimo de cuidado com a capacitação docente, os 
professores poderiam ter mais facilidade na adaptação dos seus materiais pedagógicos e, consequentemente, suas aulas seriam mais dinâmicas, pois tenderiam a refletir um equilíbrio entre os dois modelos de ensino, presencial e remoto, neste momento inicial de construção.

Ensinar de modo remoto pode parecer simples, mas não é. Ensinar online requer cuidados, tempo para investimento e o olhar crítico do professor, para verificar se aquilo que pretende ensinar atende ao: como, quando, quanto e para quem é destinado.

Entendemos que a ideia preliminar da escola era fazer "algumas" aulas online, mas a repercussão negativa da pandemia levaram-na a continuar com este projeto emergencial. Logo, a postura de "apagar incêndios" foi mantida dificultando o planejamento pedagógico remoto a médio prazo, que por sua vez, contribuiu para a continuidade dos problemas observados no início das aulas remotas, apesar dos quase três meses de suspensão das aulas presenciais.

Assim, verificamos a urgência atual da escola em pensar e buscar a resolução dos problemas observados. Até que a vacina contra o novo coronavírus esteja disponível para todos, o ensino remoto tende a ser um recurso que caminhará junto ao ensino presencial para garantir a continuidade e o acesso às aulas por todos os alunos. Logo, visando não sobrecarregar os professores, minimizar a insegurança dos pais quanto à possíveis defasagens na aprendizagem e incentivar os alunos a estudarem, a escola não pode insistir em olhar para o ensino remoto a partir das lentes do ensino presencial.

Importante destacar que o contexto atual de ensino-aprendizagem não é mais o mesmo. Alunos e professores, também se modificaram e, por isso, transpor o modelo presencial de ensino, com todas as suas características para as plataformas virtuais de aprendizagem pode não produzir os resultados almejados pela escola. Por último e, tão relevante quanto a formação acadêmica dos alunos, está o cuidado com a formação humana dos alunos e professores.

Uma educação de qualidade não é construída apenas com aulas bem estruturadas, com os conteúdos ensinados e avaliados de modo impecável, através de testes e provas. A qualidade, sobretudo, é atingida quando 
professor, aluno e pais se encontram envolvidos positivamente no processo, ou seja, quando possuem motivos que os levam à interagirem de modo ativo e dialógico, apesar dos problemas que vivenciam.

O acolhimento que a escola pode oferecer aos professores, alunos e pais, pode atenuar os aspectos negativos observados do ensino remoto e maximizar os aspectos positivos, ainda tímidos em suas expressões, mas existentes.

O mais importante da experiência que tratamos foi a percepção de professores, alunos e pais, que apesar das dificuldades enfrentadas, desenvolveram uma nova postura diante do processo de ensino-aprendizagem como um todo e descobriram novas possibilidades para ensinarem e aprenderem. Parafraseando o poeta Carlos Drummond de Andrade, descobriram que no meio do caminho tinha uma pedra e resolveram subi-la, pois a vista lá de cima permite vislumbrar todo um horizonte ainda a ser explorado.

"Com certeza, vou passar a usar algumas ferramentas nas minhas aulas futuras. Apesar da confusão que foi o uso no início, acho que deu certo. Imagina, a gente podendo usar com calma. Vai ser muito bom". (Professor, Ensino Fundamental I, escola A)

"Agora busco outros vídeos sobre as aulas na internet. Não fazia isso. Lia o caderno, o livro, as fichas e só. Agora, vejo que há muita coisa legal na internet que ajuda a estudar". (Aluno, Ensino Fundamental II, Escola B)

"Olha, as dicas de sites pedagógicos para mim, valeu! Se acho que não está muito bom, se ele ainda tem dúvida, procuro uns exercícios extras e pronto. Vou usar para sempre." (Responsável, Ensino Fundamental I, Escola A)

\section{Referências}

ARRUDA, E. P. Educação remota emergencial: elementos para políticas públicas na educação brasileira em tempos de Covid-19. EmRede, v. 7, n. 1, p. 257-275. 2020. Disponível em:

https://www.aunirede.org.br/revista/index.php/emrede/issue/view/15. Acesso em: 09/06/2020.

BURGESS, S.; SIEVERTSEN, H. H. "Schools, skills, and learning: The impact of COVID-19 on education". 2020. VOX CEPR Policy Portal 
[01/04/2020]. Disponível em: https://voxeu.org/article/impact-covid-19education. Acesso em: 02/06/2020.

DIAS, R.; LEITE, L. S. Educação a distância: da legislação ao pedagógico. Petrópolis, RJ: Vozes, 2010.

GOMES, A. L. Tecnologia em sala de aula: a inovação do ensino através da aprendizagem 3D. Educação e Cultura Contemporânea, v. 11, p. 60-84, 2014. Disponível em:

http://periodicos.estacio.br/index.php/reeduc/article/viewArticle/908. Acesso em: 04/06/2020.

KENSKY, V. M. Educação e tecnologias: o novo ritmo da informação. Campinas: Papirus, 2007.

SEN-CROWE, B.; MCKENNEY, M.; ELKBULI, A. Social distancing during the COVID-19 pandemic: Staying home save lives. American Journal of Emergency Medicine. 2020. DOI: https://doi.org/10.1016/j. ajem.2020.03.063. Acesso em: 02/06/2020.

SENHORAS, E. M. Coronavírus e educação: análise dos impactos assimétricos. Boletim de Conjuntura. V.2, n.5. 2020. Disponível em: https://revista.ufrr.br/boca/article/view/Covid-19Educacao. Acesso 02/06/2020.

VIANNA, L., ATAIDE, C. A.; FERREIRA, M. C. (2015). Educação a distância no brasil: cotidiano, prática, avanços e perspectivas. $8^{\circ}$ Encontro Internacional de Formação de Professores e $9^{\circ}$ Fórum Permanente de Inovação Educacional v. 8, n. 1. 2015. Disponível em: https://eventos.set.edu.br/index.php/enfope/article/view/1635/176. Acesso em: 09/06/2020.

RONDINI, C. A.; PEDRO, K. M.; DUARTE, C. S.. Pandemia do COVID-19 e o ensino remoto emergencial: mudanças na práxis docente. Interfaces Científicas - Educação.Disponível em: v. 10 n. 1 (2020): NÚMERO TEMÁTICO - Cenários escolares em tempo de COVID-19. Acesso em: 02/02/2021.

ZOMER, L. B.; SANTOS, A. R.; COSTA, K. C. O. O perfil de alunos do curso de administração: um estudo com base nas gerações x, y e z. Revista GUAL, Florianópolis, v. 11, n. 2, p. 198-221, maio 2018. Disponível em: file:///C:/Users/msalf_000/Downloads/54489-194991-1-PB.pdf. Acessado em: 10/06/2020. 